\title{
EFFECT OF COVID-19 ON SCHOOL EDUCATION SYSTEM: CHALLENGES AND OPPORTUNITIES TO ADOPT ONLINE TEACHING AND LEARNING
}

\author{
Sunayana Garg ${ }^{1}$, Diwakar Aggarwal ${ }^{2}$, Sushil Kumar Upadhyay ${ }^{3 *}$, Gautam Kumar ${ }^{4}$, Gulbir Singh ${ }^{5}$ \\ ${ }^{1}$ Government High School, Khad Bathlour, Takhatgarh, District Ropar, Punjab, India; ${ }^{2,3 *}$ Assistant Professor, \\ Department of Biotechnology, Maharishi Markandeshwar (Deemed to be University), Mullana- Ambala, Haryana, India; \\ ${ }^{4,5}$ Assistant Professor, MMICT \& BM(MCA), Maharishi Markandeshwar (Deemed to be University), Mullana-Ambala, \\ Haryana, India. \\ Email: ${ }^{1}$ sunayanaaggarwal@gmail.com, ${ }^{2}$ diwakaraggarwal@yahoo.co.in, ${ }^{3 *}$ upadhyay.k.sushil@gmail.com, \\ ${ }^{4}$ gautam.bopara@gmail.com, ${ }^{5}$ gulbir.rkgit@gmail.com
}

Article History: Received on $23^{\text {rd }}$ October 2020, Revised on $25^{\text {th }}$ November 2020, Published on $24^{\text {th }}$ December 2020

\begin{abstract}
Purpose of Study: Severe Acute Respiratory Syndrome Coronavirus 2 (SARS-CoV-2), deals with Coronavirus Disease 2019 (COVID-19) has instantly spread worldwide, leading to an episode of intense irresistible pneumonia. The COVID19 pandemic has created a phenomenal change in educational teaching-learning framework globally. Other than financial and social effects, there is a difficulty in adopting new online education systems by stakeholders of academic institutions.

Methodology: The review presented here is based on the platinum open access literature focusing on the adoption of the online education system during the current pandemic situation. This compilation of the findings is based on a systematic review published by the scholars of the relevant field of research targeted to opportunities and challenges in adopting ICT (Information and Communication Technology) and online teaching-learning pedagogy.
\end{abstract}

Main Findings: Specifically, school students need to deal with various sorts of ecological, electronic, and mental battles because of the COVID-19 pandemic. The whole education system from elementary to tertiary level has been imploded during the lockdown time of the COVID-19 in India and worldwide. The New Education Policy (NEP) 2020 has been delivered by the recently renamed Ministry of Education. The approach has given another face to the Online Education System in India.

Applications of this study: The finding of the current investigation is a portrayal of opportunities and challenges in receiving the online teaching-learning education system by the public and private educational institutions. It will help in the planning and development of strategies to handle the challenges and opportunities of e-learning during the current global epidemic.

Novelty of the study: The authors endeavored to address the web-based learning and teaching in the school training system in the midst of the COVID-19 pandemic. The capacity of offered resources in academic organization effectively changed conventional education into online schooling with the help of virtual classes and other urgent online gadgets in this reliably moving instructive scene.

Keywords: Coronavirus, COVID-19, SARS-CoV-2, Online Education, E-Learning, Pandemic.

\section{INTRODUCTION}

Toward the end of December 2019, an obscure emergence of viral pneumonia was first showed up in Wuhan, China, and recognized as a novel coronavirus $(\mathrm{nCoV})$ called severe acute respiratory syndrome coronavirus 2 (SARS-CoV-2) and had broaden around the world very rapidly (Heymann and Shindo, 2020; Paraskevis et al., 2020; Read et al., 2020 Kapasia et. al. (2020)). The side effects are fever, discomfort, hack, and loss of taste or smell which resolve in a couple of days in few cases; but may progress to respiratory distress and organ failure (Guan et al., 2020; Dan et al., 2020; Sood et al., 2020; Upadhyay et al., 2020a). Person-to-person transmission of SARS-CoV-2 was found to occur through respiratory globules or fomites when individuals are in close contact with a tainted human (Prajapati and Kumar, 2020; Upadhyay et al., 2020b). Regardless of this, other modes, for example, airborne transmission and contaminated utensilcontact transmission are additionally guessed (Bai et al., 2020; Dan et al., 2020; Girisha et. al.(2020)). The Director General WHO (World Health Organization) on $30^{\text {th }}$ January, 2020 announced that the episode of COVID-19 (Coronavirus Disease 2019), sets up a general wellbeing crisis of worldwide concern and issued temporary recommendations under the International Health Regulations (Zhang et al., 2020). Looking at the COVID-19 trend in India, the first novel coronavirus or SARS-Cov-2 infection was accounted for on January 30, 2020, and cases increased to three by February 3, 2020 (Upadhyay, 2020; Upadhyay et al., 2020a). The day onwards, the quantity of infected cases is ceaselessly expanding, in this way to handle the circumstance the Govt. of India called for a Janta Curfew of one day and thereafter declared complete lockdown to break the chain of coronavirus transmission (Jha et al., 2020; Upadhyay et al., 2020a, ). India's reaction to COVID-19 has been pre-emptive, proactive, favorable to dynamic, and evaluated with an elevated level of political responsibility and an 'entire Government' way to deal and react to the COVID-19 pandemic. 
Consequently, there are significant endeavors made to understand and comprehend the pathogenesis, viral properties, and expected medications to control this infection (Balfour, 2020; Yadav et al., 2020).

However, the treatments remain elusive and require further study to develop new efficient strategies for treatments. It is basic to comprehend the properties of the infection to decode another treatment. It is imperative to understand the properties of the virus to decipher a new treatment. The confirmed cases of the COVID-19 in India have risen to 7432680 with more than 795087 active cases and 112998 deaths, however, 6524595 have recovered completely by $17^{\text {th }}$ October 2020. The current review is focusing on the adoption of the online education system during the current pandemic situation and the challenges in adopting ICT (Information and Communication Technology) and online teaching-learning pedagogy.

\section{LITERATURE REVIEW}

Coronavirus disease 2019 (COVID-19) pandemic is ending up being an inventive interruption with extreme difficulties for every educational and academic institution's teaching-learning system. Simultaneously, there is a strong opportunity for us to receive more up-to-date strategies that are more reasonable for the current age of students or learners (Roberts et al., 2020; Theoret and Ming, 2020). The pandemic lockdown is still going on in a few states in India to curve down the effect of COVID-19. However, some different states are starting up with the gradual and prioritized reclamation of their exercises including teaching-learning in the education system. With standards of social distancing in setup and the rules given by the Ministry of Health and Family Welfare, Ministry of Education, UGC-Government of India, the scholarly community is probably going to proceed with the e-learning stage at any rate for not many more months (The Indian Express, 2020). With the spread of novel corona-virus disease over the globe governments shut down the educational institutes as a safety major to curb the infection after the COVID-19 pandemic e-learning is being adopted by educational ventures to fill the gap of the teaching-learning process. The education sector is exploring information technology for making teaching-learning attractive and useful (Sharma and Sharma, 2015). During the COVID-19 pandemic, educational activities moved to e-learning practices from the conventional way of education (Kumar et al. 2020). E-learning is an advanced teaching-learning methodology that uses ICT (Information and Communication Technology) to interact and collaborate. The education area is going through a very abrupt phase of improvement and confronting issues by quickly changing innovation. E-learning became a new mantra for providing education courses over long distances (Singh et al. 2020). ICT-based education helped to explore the new edges of the teaching-learning process. E-learning uncovered the new space of learning, now learning is not bound to school times and learners can access the classes/ learning material anytime. E-learning is cost-effective and ubiquitous, various platforms like DIKSHA (Digital Infrastructure for Knowledge Sharing), NROER (National Repository of Open Educational Resources), and Swayam Prabha (Group of 32 DTH channels) are being provided by Government for the students, that help them in their studies (Mishra and Dangwa, 2019; Panda, 2019; Anushalalitha, 2020; Mishra et al., 2020; $\underline{\text { Sharma et }}$ al., 2020).

The web assumed an urgent job in schooling, Google and YouTube were the profoundly material stage for instructive exercises during Govt. implemented lockdown to bend the impact of the COVID-19 pandemic, by using these platforms learners can learn at their pace (Rajhans et al., 2020). But every coin has two sides where e-learning has an advantage for learning. It has some limitations that are the challenges in adopting e-learning. E-learning has less exposure to real-time implementation for practical knowledge. Helpless web availability issues in understudy's learning assessment, and absence of correspondence during on the web classes are some significant issues looked at by the teachers and students. ICT-based training could be cutting-edge innovation for schooling however during the review individuals felt limitations of the ideal apparatuses for the teaching-learning exercises. The Internet instructing learning can't supplant the traditional procedure of education yet it can construct the conventional schooling framework more viable. Along these lines, the time has come to embrace online schooling after appropriate training of both educators and understudies. This review will be able to offer meaningful information for future planning and adoption of new teaching and learning systems during adverse circumstances. The current compilation may facilitate planning agencies' decision-making on strategies to handle the school education system during a situation like this global pandemic at the community, national, and international level. The New Education Policy (NEP) 2020 delivered by the Education Ministry has underscored the developing need for online training in India. Since the entire world is experiencing a pandemic, it has become basic that we ought to be prepared with some elective method of instruction and this is the place online training has come into the image.

\section{RESEARCH METHODS}

The ongoing pandemic has twisted the teaching and learning framework worldwide. Including financial and social impacts, there are various constraints in adopting the new education framework by students and policymakers of the academic institutions. The scope of the present research workout was explored through the use of conventional research methods and approaches that are typically employed in solving the mutual objectives of a research plan. The current research review and investigation is based on the literature survey focusing on the adoption of the online education system during the current COVID-19 scenario. This synopsis of the research account is laid out on recently published findings by several schools of the related field with key interest to opportunities and challenges in adopting ICT (Information and Communication Technology) oriented online teaching-learning pedagogy. 


\section{RESEARCH FINDINGS AND DISCUSSION}

\section{EFFECT OF COVID-19 ON SCHOOL EDUCATION}

The COVID-19 pandemic has influenced educational frameworks around the world, prompting the close all-out terminations of schools, colleges, and universities. Most governments around the globe have briefly shut educational organizations trying to trim down the stretch of COVID-19 (UNESCO, 2020). By September $4^{\text {th }}$, 2020, around 1.277 billion students are right now influenced because of school terminations in light of the pandemic. As per a UNICEF report, 46 nations are presently actualizing cross-country terminations and 27 are executing neighborhood terminations, affecting about 72.9 percent of the world's understudy populace. In 72 Nations' schools are at present open (UNESCO, 2020). According to one investigation, around 32 crore students halted to move schools/universities in India simply because of the ending of instructive exercises. As the COVID-19 pandemic continues spreading, lamentably with no medication and vaccine the WHO is encouraged to keep up social distancing and self-isolation as the main safety step. Therefore, endeavors to slow the spread of COVID-19 through non-drug mediations have provoked the widespread closure of Educational institutions worldwide (UNESCO, 2020). Past episodes of pandemic outbreaks have provoked broad school closings around the globe, with differing levels of adequacy. In this way, every nation began the activity of lockdown to isolate the contaminated individuals.

School closures contrarily impact student learning results. Schooling gives basic learning and when schools close, youngsters and youth are denied open doors for development and improvement. The weaknesses are considerably more extreme for underprivileged students who will in general have fewer educational opportunities past school (UNESCO, 2020a). At the point when schools close, guardians are regularly solicited to encourage the gaining from kids at home and can battle to play out this assignment. This is particularly valid for guardians with restricted training and resources (Mishra, 2020). School closures impact not only students, instructors, and families, yet have expansive monetary and cultural outcomes. School terminations because of the pandemic have revealed insight into different social and monetary issues, including student debt, advanced learning, food frailty, and homelessness, just as admittance to childcare, medical care, lodging, web and incapacity administrations (Barrett, 2020; Jamerson and Mitchell, 2020). The effect was more serious for impeded kids and their families, causing interrupted learning, compromised nutrition, childcare issues, and resulting monetary expense to families who couldn't work (UNESCO, 2020).

Nutrition plays a basic function in the psychological turn of events and scholarly execution for youngsters. Numerous kids overall depend on free or limited suppers at schools. At the point when schools close, nourishment is particularly undermined for youngsters in schools where food is given (McCary, 2006, , Alvi, et. al, 2020). The effect on scholastic trustworthiness has been seen the world over. A rise in contract cheating and scholarly record sharing, and test cheating were recognized as problematic (Appiah, 2020). Numerous establishments went to business administration's to assume control over test administering, yet very quickly concerns were raised about student security, reconnaissance, and the effect on student emotional well-being (Grabish, 2020). This prompted an ascent in student's fights in various nations against the utilization of the use of commercial e-proctoring services (Eaton, 2020). A portion of the significant negative effects of Coronavirus that the Education part has endured are hampering of educational activity because of terminations of schools, absence of genuine internet learning due to unpreparedness of instructors, decreased worldwide business openings. Other than these negative effects there is an expanded duty of guardians to encourage their wards where just not many instructed guardians can direct (Sahu, 2020). The vast majority of the students belonging to rural and far off territories don't approach web access and other digital accessories required for effective online instruction. The problem of delayed fee payment is additionally one of the issues; which is hampering the exercises of the establishments and making anxiety in guardians of the students (Jena, 2020a).

\section{ONLINE TEACHING-LEARNING ADOPTION: AN OPPORTUNITY}

The ongoing pandemic changed the extremely conventional, chalk-talk education model to new ambitious web-based innovation and technology. This unsettling influence in the conveyance of schooling is pushing policymakers to sort out how to drive responsibility at scale while ensuring complete e-learning action plans and taking care of the advanced digital devices. It has allowed growing as good as ever proficient aptitudes/information through internet learning more effectively and beneficially (Figure 1). Internet erudition is the most excellent arrangement amid the current pandemic circumstance (Jena, 2020b). Along these lines, the computerized India vision of the legislature is rising as an imperative apparatus for illuminating the current emergency because of Covid-19. Technology-based instruction is more straightforward with all regard (Figure 2). Keeping in view of pandemic challenges, the Universities and Schools being closed as per the legislature of India, just as state governments and private players have attempted legitimate activities (Choudhary, 2020). The Ministry of Human Resource Development (MHRD) has made a couple of strategies, including on the web entries and education channels through Direct to Home TV, Radios for understudies to continue learning. For the duration of the lockdown, understudies scholars and students are utilizing famous web-based media apparatuses like WhatsApp, Zoom, Google meets, Telegram, Youtube live, Facebook live, and so forth for the online teaching-learning system. A multi-pronged technique is critical to manage the crisis and assemble a strong Indian education structure eventually. 
Diksha platform contains e-Learning content for students, teachers, and parents adjusted to the educational program, including video works out, worksheets, course readings, and assessments. Under the direction of Central Board Secondary Education (CBSE) and National Council of Educational Research and Training (NCERT), the substance has been made by more than 250 teachers who educate in various vernaculars. The app is available to use in offline mode also. It has in excess of 80,000 digital books for classes 1 to 12 made by CBSE, NCERT in numerous dialects. Other than Diksha, different platforms like the National Repository of Open Educational Resources (NROER) entrance give a large group of assets to understudies, and educators in numerous dialects are including books, intelligent modules, and recordings including a large group of STEM-based games. Swayam is the public online training stage facilitating 1900 courses covering both school (classes 9 to 12) and advanced education (under alumni, postgraduate projects) in all subjects including designing, humanities and sociologies, law, and the board courses. Swayam Prabha has thirty two direct to home television (DTH TV) channels sending instructive substance on twenty four hours by seven days premises. These channels are accessible for surveys all over the nation utilizing DD (Doordarshan) free dish set top box and antenna. The e-PG Pathshala is dedicated to postgraduate understudies and they can utilize this platform for digital books, online courses, and study resources during the lockdown period and ongoing public health emergency (Jena, 2020a).

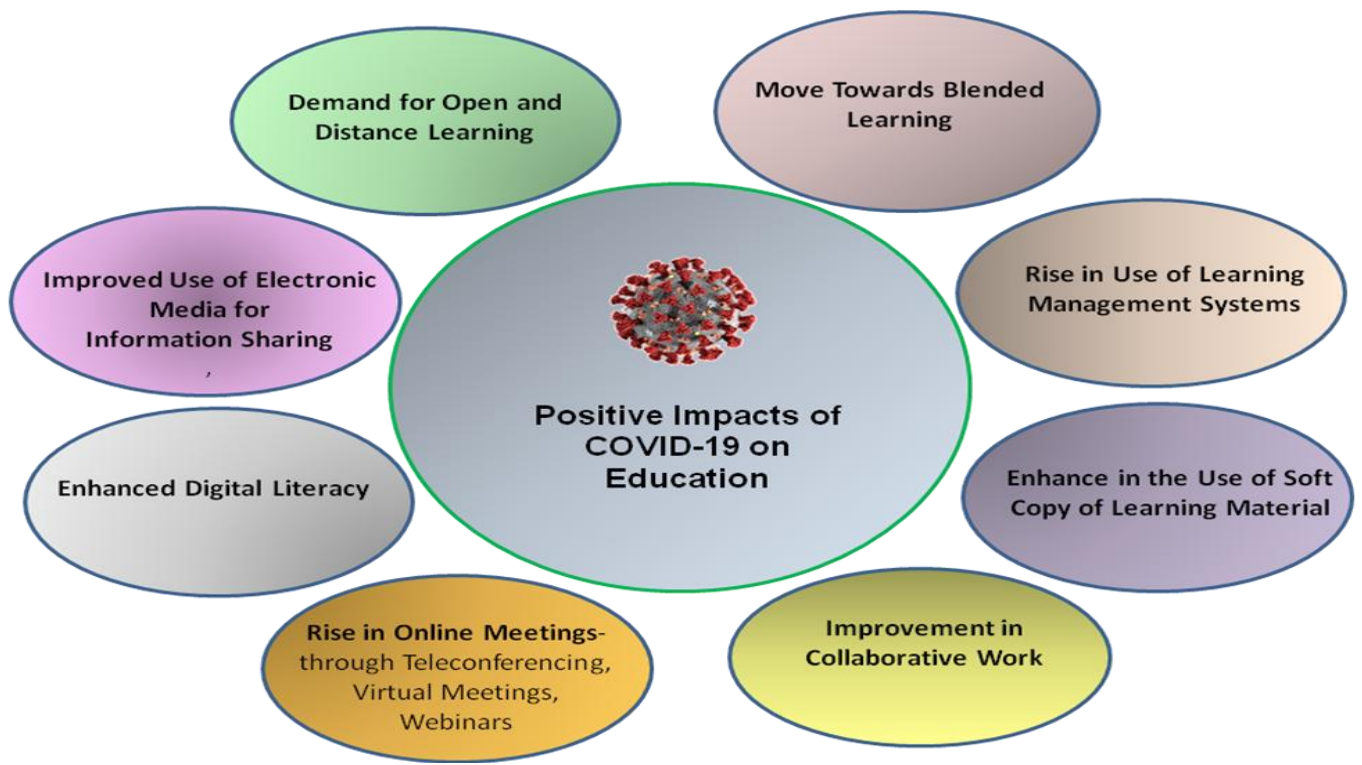

Figure 1: Positive impacts of COVID-19 in the adoption of the online education system

Source: Authors

Further, there is a need to create comprehensive learning arrangements, particularly for the most powerless and underestimated. With a speedy augmentation of versatile web customers in India, which is needed to show up at $85 \%$ nuclear families by 2024, development is enabling ubiquitous access and personalization of guidance even in the remotest bits of the country. This can change the coaching structure and augment the suitability of learning and educating, giving understudies and teachers different choices to investigate (Chopra et al., 2019). Educational institutions of India have acknowledged the demands and are making an honest effort to offer consistent help administrations to the students during the pandemic. Pandemic has accelerated the adoption of advanced innovations to deliver education. Instructive organizations moved towards a mixed method of learning. It supported all educators and students to turn out to be more innovative and insightful. The utilization of learning the board frameworks by educational institutions turned into an incredible interest. The use of a soft copy of the learning material has improved. There is a gigantic demand for open and distance learning courses (Gupta and Gupta, 2020).

\section{CHALLENGES IN ADOPTING ONLINE TEACHING-LEARNING}

Besides the willingness of a larger part of educators and students in schools and other educational foundations towards utilization of different computerized and E-learning platforms, the most well-known difficulties looked by both understudies and instructors are technical issues, interruptions and time management, staying motivated, understanding course expectations, absence of in-person interaction, adjusting to innovation and vulnerability about the future (Mallak, 2001) (Fig. 2). Indeed, fundamental e-learning components are absent, for example, PCs, power, skills, and dynamic cooperation of students and instructors in distant and not so developed regions of the country (Andersson \& Gronlund 2009). The greatest challenge most likely sets in guaranteeing that specific preconditions are required for e-learning, for example, admittance to ICT apparatuses and network foundation. Orienting the perception of instructors and students in favor of e-learning and persuading them to acknowledge it is additionally also very crucial (Fig. 2). Another perspective that should be taken care of is the specialized competency of the individuals which will connect with the e-learning scheme. One of the most widely recognized issues revealed by both the partners is that there were no experts to prepare 
them in the utilization of e-learning stages and that there was insufficient preparation when it went to the utilization of the innovation (Aung and Khaing, 2015).

The cost of getting, overseeing, and keeping up ICT Infrastructure has been recognized as a significant hindrance in the course of action and determination of e-Learning by organizations and academic bodies. A portion of the elements, for example, inadequately prepared lecture rooms and absence of power have frustrated the organization and the resulting selection of e-adapting, particularly in rustic and remote territories. Further absence of a legitimate e-learning educational program is a significant boundary to the successful sending and reception of e-learning. Another course issue is the conveyance method of the course. The factor concerns whether understudies ought to be permitted to pick the mode of content delivery ( Shahzad et al., 2020).

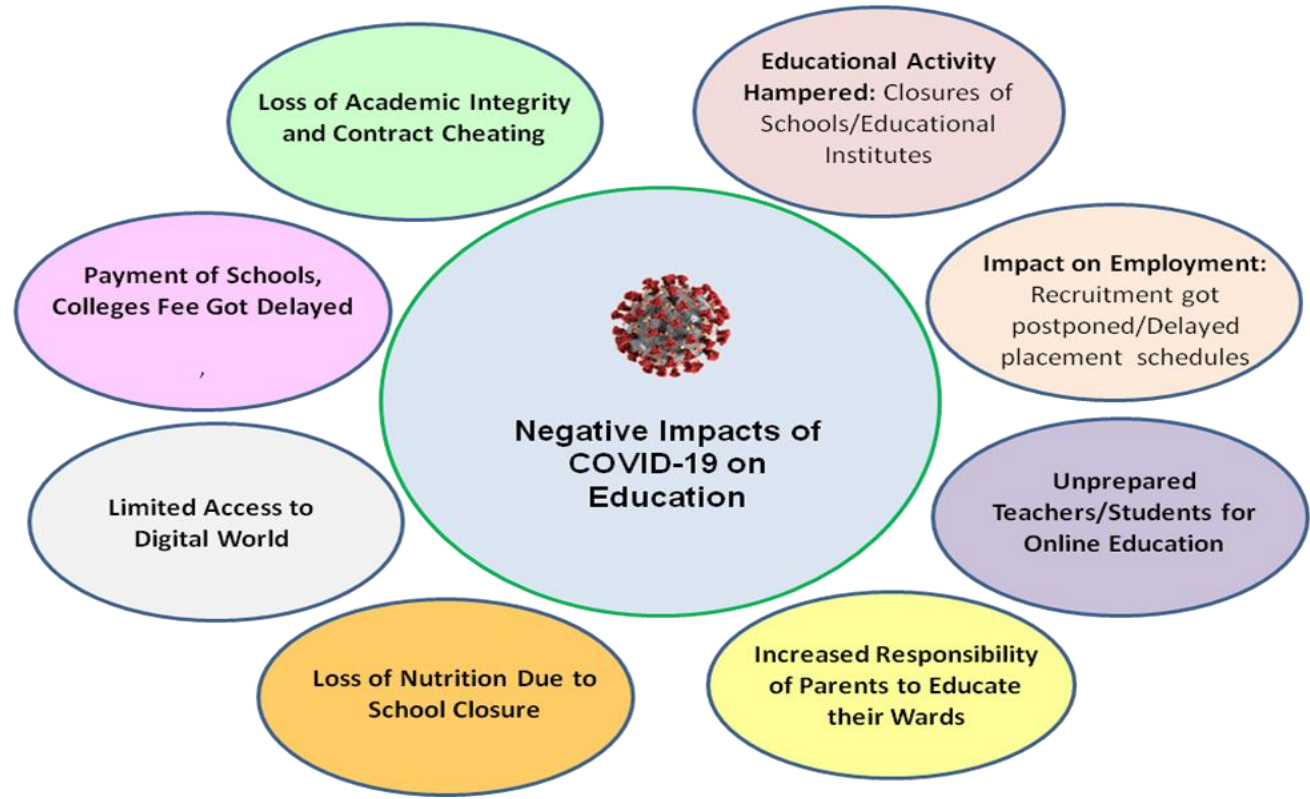

Figure 2: Negative impacts of COVID-19 in the adoption of the online education system

Source: Authors

Educators who are deficiently prepared in their subjects, and have next to zero PC experience are a block to a successful organization and reception of online learning in institutions. The blending of ICT advances would necessitate noteworthy pre-administration and in-administration instructors preparing in fundamental PC proficiency just as how to educate with e-learning advances for powerful sending and reception of e-learning in educational institutes (Di Vaio et al., 2020). Specialized aptitudes are a huge part of the execution and incorporation of e-learning innovations in the instruction framework. Establishment, accessibility of the most recent technologies, quick web association, continuous delivery of electric power, up to date maintenance, organizational administration, security, and lack of skilled technical assistance are different big issues.

Understudies having low capability are not prone to utilize e-learning due to low trust in understanding the substance of English composed materials. One study found that the vast majority of the respondents felt the language was a hindrance to e-learning. Other than these significant difficulties, the challenge of interruptions, time management, and remaining roused for e inclining are other significant issues of concern (Chopra et al., 2019). There is a need to reconsider the current conveyance and instructive methodologies in school and high level training through impeccably planning classroom learning with e-learning modes to construct a unified learning system. The critical challenge at the public level is the predictable addition of new technology in the current Indian teaching system, which is the most unique and greatest on earth with more than 15 lakh schools and 50,000 high level educational organizations.

\section{CONCLUSION}

India is a demographically miscellaneous enormous nation with immense populace density. The cross-country lockdown was the main procedure in the battle against the COVID-19 pandemic that began on March $25^{\text {th }}$, 2020. The Covid-19 pandemic appears to have proclaimed another adjustment in the education system over the world. The COVID-19 pandemic and its disturbances have made an open door for the rebuilding of the school education framework. Computerized learning has been the usual methodology of experts glancing to upskill in an inexorably robotized world, e-learning found a spot in the educational plans of schools and colleges in the midst of the lockdown to guarantee scholastic coherence. Yet, moving educational practices online in the midst of winning challenges can't fill in as a drawn-out arrangement. The brisk changes to online mode helped with keeping coherence of school education programs, successfully fitting in the reason for the utilization of the ongoing scholastic year. The excursion from conventional model of training to a competency-based learning curriculum has started. Online teaching, Web-based learning, 
utilization of information, and communication innovation technologies in school education is lay down to turn into a new normal. The change can be snappy and smooth if teachers and specialized staff show a versatile, acceptable, applicable, and collaborative attitude. It is however very untimely scheduled to finish up the fruitful story of progress as the verdict of understudies' presentation and excellence of passing out partners or stakeholders is yet to be figured out. Further examinations might be coordinated to test students' performance constantly and fulfill on switching to the elearning education system. The New Education Policy (NEP) 2020 is intended to augment the advantages of advanced and online instruction in India while alleviating the disadvantages. The new training approach has accompanied a few activities involving Pilot studies and the establishment of virtual labs.

\section{LIMITATIONS AND FUTURE SCOPE}

User-friendly and trustworthy technology is critical to a successful online teaching-learning process. Lamentably, the majority of the partners of scholarly organizations never utilized ICT-based schooling, the current COVID-19 pandemic that uncovered the absence of inspiration, preparing, and commitment of understudies and educators as well. E-learning could be a front line innovation for schooling yet during the COVID-19 pandemic, individuals felt requirements of the ideal apparatuses for the educating learning activities. This finding will help design and implement policies to tackle an adverse situation in the future for incessant functioning of the education system by employing basic facilities provided by the governing authorities.

\section{ACKNOWLEDGEMENT}

We are thankful to Government High School, Khad Bathlour, and Maharishi Markandeshwar (Deemed to be University) for their support to conduct inter-institutional collaborative research.

\section{AUTHORS CONTRIBUTION}

Sunayana Garg: Conceptualization and drafting of the current investigation.

Diwakar Aggarwal: Literature survey and writing original draft and figures formulation.

Sushil Kumar Upadhyay: Supervision, writing introduction, and editing of the manuscript.

Gautam Kumar: Methodology writing, editing of the manuscript, formal analysis, and application.

Gulbir Singh: Writing-editing of the manuscript and formal analysis.

\section{REFERENCES}

1. Alvi, M., Gupta, M. (2020). Learning in times of lockdown: how Covid-19 is affecting education and food security in India. Food Sec., 12, 793-796.

2. Andersson, A., Gronlund, A. (2009). A Conceptual framework for e-learning in developing countries: A critical review of research challenges. The Electronic Journal on Information Systems in Developing Countries, 38(8): 116.

3. Anushalalitha, T. (2020). Open education resources and new age teachers. In: Auer M., Ram B. K. (eds) Cyberphysical systems and digital twins. Lecture notes in networks and systems, Springer, Cham, 80. https://doi.org/10.1007/978-3-030-23162-0_67

4. Appiah, K.A. (2020). If my classmates are going to cheat on an online exam, Why can't I? New York Times, https://www.nytimes.com/2020/04/07/magazine/if-my-classmates-are-going-to-cheat-on-an-online-exam-whycanti.html

5. Aung, T.N. and Khaing, S.S. (2015). Challenges of implementing e-learning in developing countries: A review. In: T. T. Zin et al. (eds.), Genetic and evolutionary computing, advances in intelligent systems and computing 388. https://doi.org/10.1007/978-3-319-23207-2_41

6. Bai, Y., Yao, L., Wei, T., Tian, F., Jin, D.Y., Chen, L., Wang, M. (2020). Presumed asymptomatic carrier transmission of COVID-19. Journal of American Medical Association, 323(14):1406-1407. https://doi.org/10.1001/jama.2020.2565

7. Balfour, H. (2020). Coronavirus update: Recent developments in novel coronavirus (COVID-19 or SARS-CoV-2) therapeutics and vaccine research. Drug Target Reviews, 56607.

8. Barrett, S. (2020). Coronavirus on campus: College students scramble to solve food insecurity and housing challenges. Consumer News and Business Channel, https://www.cnbc.com/2020/03/23/coronavirus-on-campusstudents-face-food-insecurity-housing-crunch.html

9. Chopra, G., Madan, P., Jaisingh, P., Bhaskar, P. (2019). Effectiveness of E-learning portal from students' perspective: A structural equation model (SEM) approach. Interactive Technology and Smart Education, 16(2): 94-116. https://doi.org/10.1108/ITSE-05-2018-0027

10. Choudhary, R. (2020). COVID-19 Pandemic: Impact and strategies for education sector in India. E-learning: COVID-19 Pandemic: Impact and strategies for education sector in India. Government News, Published 16.04.2020, retrieved on 17.09.2020. 
11. Dan, S., Pant, M., Upadhyay, S.K. (2020). The case fatality rate (CFR) in SARS-COV-2 patients with cardiovascular disease (CVD): A global health risk paradigm in COVID-19 pandemic. Current Pharmacology Reports, 6(6): 315-324. https://doi.org/10.1007/s40495-020-00239-0

12. Di Vaio, A., Palladino, R., Hassan, R., and Alvino, F. (2020). Human resources disclosure in the EU Directive 2014/95/ EU perspective: A systematic literature review. The Journal of Cleaner Production, 257: 120509. https://doi.org/10.1016/j.jclepro.2020.120509

13. Eaton, S.E. (2020). E-Proctoring: Understanding the debate about invigilating remote exams. https://drsaraheaton.wordpress.com/2020/05/12/e-proctoring-understanding-the-debate-about-invigilating-remoteexams/

14. Girisha L. P. G, Srikaanth, P. B., Upadhyay, S. K., Kumar, G., Singh, G., Yadav, D., Babita, Subbiah, R., Kodam, S., Biswal, C., Rahulji, D., Bhardwaj, M., Sharma, A., Pathak, A.(2020). The internet of things based smart mattresses for somnambulism (sleepwalking) patient. India Patent No. 202041032387. Intellectual Property India.

15. Grabish, A. (2020). University of Manitoba uses anti-cheating software to monitor remote exams. Canadian Broadcasting Corporation News. https://www.cbc.ca/news/canada/manitoba/anti-cheating-software-university-ofmanitoba-1.4223737

16. Guan, W., Ni, Z., Hu, Yu, Liang, W., Ou, C., He, J., Liu, L., Shan, H., Lei, C., Hui, D.S.C., Du, B., Li, L., Zeng, G., Yuen, K.Y., Chen, R., Tang, C., Wang, T., Chen, P., Xiang, J., Li, S., Wang, J., Liang, Z., Peng, Y., Wei, L., Liu, Y., Hu, Y., Peng, P., Wang, J., Liu, J., Chen, Z., Li, G., Zheng, Z., Qiu, S., Luo, J., Ye, C., Zhu, S. and Zhong, N. (2020). Clinical characteristics of coronavirus disease 2019 in China. New England Journal of Medicine, 382: 1708-1720. https://doi.org/10.1056/NEJMoa2002032

17. Gupta, S.B., Gupta, M. (2020). Technology and e-learning in higher education. Technology, 29(4): 1320-1325.

18. Heymann, D.L., Shindo, N. (2020). COVID-19: What is next for public health? Lancet. https://doi.org/10.1016/S0140-6736(20)30374-3

19. Jamerson, J., Mitchell, J. (2020). Student-loan debt relief offers support to an economy battered by coronavirus. Wall Street Journal. https://www.wsj.com/articles/student-loan-debt-relief-offers-support-to-an-economy-batteredby-coronavirus-11584735842

20. Jena, P.K. (2020a). Impact of pandemic COVID -19 on education in India. International Journal of Current Research, 12(07): 12582-12586. https://doi.org/10.31235/osf.io/2kasu

21. Jena, P.K. (2020b). Online learning during lockdown period for covid-19 in India. International Journal of Educational Research, 9 (5): .82-92. https://doi.org/10.31235/osf.io/qu38b

22. Jha, D., Sharma, V., Sharma, J.K., Kumar, S., Sharma, V., Kamboj, P., Upadhyay, S.K., Sharma, A.K. (2020). Plausible state-specific plans and recommendations to avert COVID-19 community transmission. Bulletin of Pure and Applied Sciences Zoology. 39A(2): 447-454. https://doi.org/10.5958/2320-3188.2020.00051.0.

23. Kapasia. N., Paul P., Roy A., Saha J., Zaveri A., Mallick R., Barman B., Das P., Chouhan P. (2020). Impact of lockdown on learning status of undergraduate and postgraduate students during COVID-19 pandemic in West Bengal, India. Children and Youth Services Review. 116, 105194, 2020. https://doi.org/10.1016/j.childyouth.2020.105194.

24. Kumar, G., Singh, G., Bhatnagar, V., Gupta, R., Upadhyay, S. K. (2020). Outcome of Online Teaching-Learning over Traditional Education during Covid-19 Pandemic. International Journal of Advanced Trends in Computer Science and Engineering, 9(5), 7704-7711. https://doi.org/10.30534/ijatcse/2020/113952020

25. Mallak, L.A. (2001). Challenges in implementing e-learning. Institute of Electrical and Electronics Engineers, https://doi.org/10.1109/PICMET.2001.952186

26. McCary, J.M. (2006). Improving access to school-based nutrition services children with special health care need. Journal of the American Dietetic Association, 106(9): 1333-1336. https://doi.org/10.1016/j.jada.2006.07.022

27. Mishra, D. and Dangwa, K.L. (2019). Web-based education: History and scope in India. Journal of The Gujarat Research Society, 21(5): 461-467.

28. Mishra, K. (2020). Covid-19: 4 negative impacts and 4 opportunities created for education. https://www.indiatoday.in/education-today/featurephilia/story/covid-19-4-negative-impacts-and-4-opportunitiescreated-for-education-1677206-2020-05-12. Accessed on 25.09.2020

29. Mishra, L., Gupta, T, Shree, A. (2020). Online teaching-learning in higher education during lockdown period of COVID-19 pandemic. International Journal of Educational Research. https://doi.org/10.1016/j.ijedro.2020.100012

30. Panda, S. (2019). Evaluation of online course on understanding open educational resources. The Commonwealth of Learning. http://hdl.handle.net/11599/3216. pp1-52

31. Paraskevis, D., Kostaki, E.G., Magiorkinis, G., Panayiotakopoulos, G., Sourvinos, G., Tsiodras, S. (2020). Fullgenome evolutionary analysis of the novel corona virus $(2019-\mathrm{nCoV})$ rejects the hypothesis of emergence as a result of a recent recombination event. Infection, Genetics and Evolution, 79: 104212. https://doi.org/10.1016/j.meegid.2020.104212

32. Prajapati S., and Kumar, N. (2020). SARS-CoV-2 pandemic: An opportunity for Indian traditional medicines (AYUSH). International Journal of Complementary and Alternative Medicine, 13(3): 103-105. https://doi.org/10.15406/ijcam.2020.13.00502

33. Rajhans, V., Memon, U., Patil, V., Goyal, A. (2020). Impact of COVID-19 on academic activities and way forward in Indian optometry. Journal of Optometry, 13(4): 216-226. https://doi.org/10.1016/j.optom.2020.06.002 
34. Read, JM., Bridgen, JRE., Cummings, DAT., Ho, A., Jewell. C.P. (2020). Novel coronavirus 2019-nCoV: Early estimation of epidemiological parameters and epidemic predictions, MedRxiv Preprint, 2020. https://doi.org/10.1101/2020.01.23.20018549

35. Roberts, D.H., Newman, L.R., Schwartzstein, R.M. (2012). Twelve tips for facilitating Millennials' learning. Medical Teacher, 34: 274-278. https://doi.org/10.3109/0142159X.2011.613498

36. Sahu, P. (2020). Closure of universities due to Coronavirus Disease 2019 (COVID-19): Impact on education and mental health of students and academic staff. Cureus Journal of Medical Science. https://doi.org/10.7759/cureus. 7541

37. Shahzad A, Hassan R, Aremu AY, Hussain A, Lodhi RN (2020). Efects of COVID19 in Elearning on higher education institution students: The group comparison between male and female. Quality and Quantity, https://doi.org/10.1007/s11135-020-01028-Z

38. Sharma S., Sharma P. (2015). Indian higher education system: Challenges and suggestions. The Electronic Journal for Inclusive Education, 3(4): 1-5.

39. Sharma, K., Gandhi, R. and Sharma, M. (2020). Government initiatives for continuing school education during lockdown: A study of government schools in Pratapgarh district of Rajasthan. Mukt Shabd Journal, 9(6): 34883499.

40. Singh, G., Bhatnagar, V., Gupta, R., Kumar, G. (2020). Exploration of e-learning vs traditional learning in India. Humanities and Social Sciences Reviews, 8(2), 69-76. https://doi.org/10.18510/hssr.2020.829

41. Sood, S., Aggarwal, V., Aggarwal, D., Upadhyay, S.K., Sak, K., Tuli, H.S., Kumar, M., Kumar, J., Talwar, S. (2020). Covid-19 pandemic: From molecular biology, pathogenesis, detection and treatment to global societal impact. Current Pharmacology Reports, 6(5): 212-227. https://doi.org/10.1007/s40495-020-00229-2

42. The Indian Express (2020). Teacher training, social distancing: here's how Indian universities will function postlockdown. https://indianexpress.com/article/education/ugc-calendar-2020-how-will-indian-universities-functionpost-lockdown-ugc-panel-6385273/

43. Theoret C., Ming X. (2020). Our education, our concerns: Medical student education impact due to COVID19. Medical Education. https://doi.org/10.1111/medu.14181

44. UNESCO (2020). Education: From disruption to recovery. https://en.unesco.org/news/covid-19-educationaldisruption-and-response, Accessed on 03.10.2020

45. UNESCO (2020a). Adverse consequences of school closures. https://en.unesco.org/covid19/ educationresponse/consequences. Accessed on 03.10.2020

46. Upadhyay, S.K., Singh, R., Babita, Kumar, G., Singh, G. (2020a). The outbreak and challenges of novel coronavirus (COVID-19): The global pandemic emergency of early 2K20 and Indian scenario. International Journal of Biology, Pharmacy and Allied Sciences, 9: 1173-1199. https://doi.org/10.31032/IJBPAS/2020/9.5.5126

47. Upadhyay, S.K., Singh, R., Singh, M., Kumar, V., Yadav, M., Aggarwal, D., Sehrawat, N. (2020b). COVID-19 in republic of India: A report on situation and precautionary strategies to global pandemic. Bulletin of Environment, Pharmacology and Life Sciences, 9: 39-48.

48. Upadhyay, S.K. (2020). Droplet borne deadly contagious coronavirus (COVID-19): Transboundary public health emergency in early 2020. Everyman's Science, 55(1): 4p.

49. Yadav, R., Parihar, R.D., Dhiman, U., Dhamija, P., Upadhyay, S.K., Imran, M., Behera, S.K. and Prasad, T.S.K. (2020). Docking of FDA approved drugs targeting NSP-16, N-protein and main protease of SARS-CoV-2 as dual inhibitors. Biointerface Research in Applied Chemistry. 11(3): 9848-9861. https://doi.org/10.33263/BRIAC113.98489861.

50. Zhang, D., Wu, K., Zhang, X., Deng, S., Peng, D. (2020). In silico screening of Chinese herbal medicines with the potential to directly inhibit 2019 novel coronavirus. Journal of Integrative Medicine. https://doi.org/10.1016/j.joim.2020.02.005 